\title{
Inhibitory Effects of Chinese Medicinal Herbs on Plant-Pathogenic Bacteria and Identification of the Active Components from Gallnuts of Chinese Sumac
}

C. T. Feng, Institute of Biological Resource, National Pingtung University of Science \& Technology, Neipu 91201, Taiwan; H. J. Su, Department of Nursing, Meiho University, Neipu, 91202, Taiwan; C. T. Chen, Institute of Biological Resource, National Pingtung University of Science \& Technology, Neipu 91201, Taiwan; W. C. Ho, Department of Biotechnology, Tajen University, Yenpu, Pingtung 09741, Taiwan; and Y. R. Tsou and L. L. Chern, Department of Plant Medicine, National Pingtung University of Science \& Technology, Neipu 91201, Taiwan

\begin{abstract}
Feng, C. T., Su, H. J., Chen, C. T., Ho, W. C., Tsou, Y. R., and Chern, L. L. 2012. Inhibitory effects of Chinese medicinal herbs on plant-pathogenic bacteria and identification of the active components from gallnuts of Chinese sumac. Plant Dis. 96:1193-1197.

The aqueous extracts of 30 out of 67 Chinese medicinal herbs were shown to have inhibitory effects on growth of Xanthomonas euvesicatoria by a paper disc diffusion assay. The inhibitory substances with the strongest antibacterial activity were extracted from Chinese sumac gallnut and black myrobalan. The aqueous extract of gallnut inhibited the growth of eight of the tested plant-pathogenic bacteria, and that of black myrobalan inhibited five. The gallnut extract produced at least an 8-mm inhibition zone against Acidovorax citrulli, Ralstonia solanacearum, X. citri pv. citri, and $X$. euvesicatoria at a 10 -fold dilution, and it was still active at 800 - to 1,600-fold dilutions. The aqueous extract of gallnut was more inhibitory than the acetone-water extract. To identify the inhibitory compounds in the gallnut aqueous extract, the crude extract was

chromatographed over a silica column, and the primary compounds in fractions 3 and 8 were identified by nuclear magnetic resonance as gallic acid and methyl gallate, respectively. The inhibitory effect of methyl gallate on the growth of four plant-pathogenic bacteria was 10 to 80 times that of gallic acid. The minimum inhibition and minimum bactericidal concentration tests showed that the inhibition effect of the original aqueous was higher than that of methyl gallate. These results indicate that methyl gallate in gallnut is an important compound that is inhibitory to plant-pathogenic bacterial growth, and there are other unidentified compounds that are also responsible for the antibacterial effects. This is the first report regarding the antibacterial effects of gallnut extract and its chemical components on plant-pathogenic bacteria.
\end{abstract}

Plant-pathogenic bacteria can attack many crops in various growth stages and result in substantial yield losses. The important bacterial diseases in the field include bacterial fruit blotch, which is caused by Acidovorax citrulli on watermelon and cucurbit (9), bacterial wilt caused by Ralstonia solanacearum (11), bacterial leaf spot caused by Xanthomonas euvesicatoria on tomato and pepper (17), and bacterial canker caused by X. citri pv. citri on citrus (18).

The bacterial fruit blotch of watermelon is a seedborne disease and can be controlled by treating the seed with bactericides or hydrochloric acid (5). The pathogens that cause bacterial leaf spot and citrus bacterial canker are primarily transmitted by rain water and controlled by bactericides. The use of large quantities of pesticides often induces microorganisms to become resistant and causes environmental pollution (16). Furthermore, bacterial wilt of tomato is a soilborne disease, and it cannot be effectively controlled by pesticide application (14). Therefore, it is critical to find alternative materials that can be used to control bacterial diseases.

Many plant-derived materials are effective in controlling plant diseases and generally pose less of a threat to the environment than many conventional pesticides $(11,19)$. The extracts from a number of plants are known to contain substances that inhibit plant-pathogenic fungi and bacteria $(8,15,20,22)$. Many essential oils have been shown to possess antibacterial properties active against a wide range of bacteria $(10,19)$. The extracts and essential oils from thyme and oregano (19) and the extracts of Allium sativum and Ficus carica (3) have been developed for use by growers to control bacterial wilt and bacterial spot.

Corresponding author: L. L. Chern, E-mail: 1lchern@ mail.npust.edu.tw

Accepted for publication 12 March 2012.

doi:10.1094/PDIS-08-11-0673-RE

(C) 2012 The American Phytopathological Society
In a previous study, gallnut was shown to be one of the best Chinese medicinal herbs with respect to its strong antifungal effects (8), but its inhibitory effect on plant-pathogenic bacteria has not been tested. In this study, the aqueous extracts of 67 medicinal herbs were bioassayed to determine their antibacterial activity against plant-pathogenic bacteria. The aqueous extract of the herb that had the best effect was purified to identify its inhibitory compounds. The results showed that the Chinese sumac gallnut was useful in controlling plant bacterial diseases, and some of the antibacterial effects in its aqueous extract were derived from the chemical methyl gallate.

\section{Materials and Methods}

Bacterial strains and chemicals. The eight species and nine strains of plant-pathogenic bacteria that were used in this study are listed in Table 1. Two strains of $X$. euvesicatoria were used. Strain XVP-197 was used to screen for the antibacterial effects of the aqueous extracts, and strain XVT-28 was used in all of the other tests. The bacteria were maintained on medium 523, which consisted of $1 \%$ sucrose, $0.8 \%$ casein, $0.4 \%$ yeast extract, $0.2 \%$ $\mathrm{K}_{2} \mathrm{HPO}_{4}, 0.05 \% \mathrm{MgSO}_{4}$, and $2 \%$ agar (12), and all of the bioassays were also carried out on this medium unless otherwise stated. The bacterial suspensions of the tested species were prepared from the colonies that were grown on medium 523 at $28^{\circ} \mathrm{C}$ for $72 \mathrm{~h}$.

The commercial products of pure gallic acid and methyl gallate were purchased from Sigma (St. Louis, MO, USA) and Fluka (Buchs, Switzerland), respectively, for the comparison. Streptomycin was used as the positive control and was purchased from Sigma.

Preparation of Chinese herb aqueous extracts and extraction with acetone-water. Chinese medicinal herbs (Table 2) were purchased from the Chuen-Ho-Tang Chinese Medicine Store, Taitung, Taiwan, and consisted of dried bark, seeds, flowers, fruits, rhizomes, roots, stems, whole plants, or gallnuts. The gallnut that was used in this study was the abnormal growth produced on leaves of Chinese sumac (Rhus chinensis) in response to an infestation by 
the parasitic aphid Melaphis chinensis. The herbs were crushed with a mortar and pestle, placed in 250-ml flasks at a ratio of one part herb to 10 parts distilled water, autoclaved for $20 \mathrm{~min}$, and filtered through Whatman No. 1 filter paper to produce a 10-fold dilution (wt/vol) of aqueous extracts under aseptic conditions. When different concentrations of the aqueous extract were prepared, the extract was freeze-dried with a freeze-drier (Kingmech Co., LTD., Taiwan) and then dissolved in sterile distilled water. The acetone extract of the gallnut was prepared by twice soaking one part of the herb in five parts of acetone-water $(2: 1)$ for $48 \mathrm{~h}$. The solvent extracts were pooled and evaporated to dryness with a vacuum evaporator (N-1000SW, EYELA, Japan) (4).

Column chromatography and chemical identification. In order to determine which compounds in the gallnut aqueous extract contained the antibacterial properties, aqueous extract of $4 \mathrm{~kg}$ of gallnut was prepared and freeze-dried as described above. The dry matter of the crude extract was chromatographed over silica gel by column chromatography (70 to $230 \mathrm{mesh}, 10 \times 65 \mathrm{~cm}$ ). Elution started with a gradient of $n$-hexane/acetone with $10 \%$ increment of acetone from 0 to $100 \%$ and 5 liters of mobile phase in each step, followed by a gradient of acetone/methanol with $10 \%$ increment of methanol from 0 to $100 \%$ and 5 liters in each step, and $95 \%$ methanol at the end. The fractions were analyzed by thin layer chromatography (TLC) (Silica gel 60, Merck) with $n$-hexane:ethyl acetate:methanol 1:4:1 as mobile phase, and those fractions that had similar patterns were combined. Gallic acid and methyl gallate were used as references because they were shown to be inhibitory toward bacterial growth (1). The fractions that contained inhibitory substances were further purified on silica gel (230 to 400 mesh) columns and eluted with $n$-hexane:acetone 2:3 (5 liters), followed by $n$-hexane:ethyl acetate:methanol 3:4:1 (2 liters) to elute gallic acid, or by $n$-hexane/acetone 1:2 (2.5 liters) to elute methyl gallate. The purity of each compound was analyzed by TLC and by identification with nuclear magnetic resonance (NMR) spectroscopic analysis (Varian INOVA Oxford-500 FT-NMR spectrometer).

Bioassay of inhibitory effect by the paper disc diffusion assay. Two loops of bacterial strain were suspended in $9 \mathrm{ml}$ of sterile distilled water to create a $10^{8} \mathrm{CFU} / \mathrm{ml}$ suspension. An aliquot of $200 \mu \mathrm{l}$ of the bacterial suspension was placed on a 9-cm-diameter agar plate that contained medium 523. The suspension was spread evenly over the agar surface with a sterile L-glass rod. Paper discs (6 $\mathrm{mm}$ in diameter, with an absorption capacity of approximately $10 \mu \mathrm{l})$ of Whatman No. 1 filter paper that were soaked in the aqueous extracts of the herbs for $10 \mathrm{~min}$, then air-dried, were placed on the agar surface. Discs that were soaked in sterile distilled water were used as a control. All of the plates were incubated at $28^{\circ} \mathrm{C}$ for $72 \mathrm{~h}$ before the inhibition (clear) zone was measured. Three discs were used for each treatment, and all of the experiments were repeated twice.

The aqueous extracts of 67 Chinese herbs were tested against strain XVP-197 of X. euvesicatoria. The aqueous extracts of gallnut and black myrobalan (Terminalia chebula), two of the herbs

Table 1. List of the plant-pathogenic bacteria used in this study

\begin{tabular}{llll}
\hline Plant-pathogenic bacteria & Strains & Host & Source $^{\mathbf{z}}$ \\
\hline Acidovorax citrulli & AAC-33 & Watermelon & NCHU \\
Burkholderia cepacia & PC & Onion & AVRDC \\
B. gladioli pv. gladioli & PK-11 & Onion & AVRDC \\
Pectobacterium carotovorum & PCC & Phalaenopsis & NCHU \\
P. chrysanthemi & PCH & Cabbage & NCHU \\
Ralstonia solanacearum & EPS-1 & Egg plant & Ping Tech. \\
Xanthomonas euvesicatoria & XVT-28 & Tomato & AVRDC \\
& XVP-197 & Pepper & AVRDC \\
X. citri pv. citri & XPL-2 & Citrus & Ping Tech. \\
\hline
\end{tabular}

${ }^{\mathrm{z}}$ NCHU: National Chung Hsing University, Taichung, Taiwan; AVRDC: AVRDC-The World Vegetable Center, Tainan, Taiwan; Ping Tech.: National Pingtung University of Science and Technology, Pingtung, Taiwan.
Table 2. Inhibitory effects of the aqueous extracts of Chinese medicinal herbs on the growth of Xanthomonas euvesicatoria XPV-197

\begin{tabular}{|c|c|c|}
\hline Chinese medicine & Plant species & $\begin{array}{c}\text { Inhibition } \\
\text { zone }(\mathrm{mm})^{\mathrm{y}}\end{array}$ \\
\hline Chinese gallnut $^{\mathrm{z}}$ & Rhus chinensis & 6.8 \\
\hline Black myrobalan & Terminalia chebula & 6.6 \\
\hline Amur cork tree & Phellodendron amurense & 4.4 \\
\hline Moutan cortex & Paeonia suffruticosa & 4.2 \\
\hline Clove & Syzygium aromaticum & 3.7 \\
\hline Ledebouriella & Saposhnikovia divaricata & 3.5 \\
\hline Cinnamon (bark) & Connamoтum cassia & 3.5 \\
\hline Chinese gentian & Gentiana scabra & 2.9 \\
\hline Anemarrhena & Anemarrhena asphodeloides & 2.7 \\
\hline Trichosanthes & Trichosanthes kirilowii & 2.3 \\
\hline Magnolia & Magnolia officinalis & 2.3 \\
\hline Lesser galangal & Alpinia officinarum & 2.1 \\
\hline Madder & Rubia cordifolia & 2.0 \\
\hline Baical skullcap & Scutellaria baicalensis & 1.9 \\
\hline Barvat skullcap & Scutellaria barbata & 1.8 \\
\hline Citric manbalen & Phyllanthus emblica & 1.7 \\
\hline Perillae herba & Perilla frutescens & 1.7 \\
\hline Yedeon violet & Viola yedoenisis & 1.7 \\
\hline Stemona & Stemona seddilifolia & 1.5 \\
\hline Angelica & Angelica dahurica & 1.4 \\
\hline Zicao & Arnebia eucbroma & 1.4 \\
\hline Selfheal & Prunella vulgaris & 1.4 \\
\hline Chinese rhubarb & Rheum officinale & 1.4 \\
\hline Wolfberry & Lycium chinense & 1.3 \\
\hline Honeysuckle & Lonicera japonica & 1.1 \\
\hline Eucommia & Eucommia ulmoides & 1.1 \\
\hline Polygonati & Polygonatum sibiricum & 1.0 \\
\hline Chinese Wolfberry & Lycium barbarum & 0.8 \\
\hline Asparagus & Asparagus cochinensis & 0.8 \\
\hline Coral bean & Erythrina indica & 0.8 \\
\hline Yinchenhao & Artemisia scoparia & 0 \\
\hline Asarum & Asarum heterotropoides & 0 \\
\hline Acanthopanax & Acanthopanacis gracilistylus & 0 \\
\hline Atractylodes & Atractylodes macrocephala & 0 \\
\hline Agrimony & Agrimonia pilosa & 0 \\
\hline Notoginseng radix & Anredera cordifilia & 0 \\
\hline Chinese angelica & Angelica sinensis & 0 \\
\hline Hangse & Astragalus membranceus & 0 \\
\hline Milk vetch & Astragalus membranceus & 0 \\
\hline Myrrha & Abrus precatorius & 0 \\
\hline Belamcanda & Belamcanda chinensis & 0 \\
\hline Vaccaria & Baccaria segetalis & 0 \\
\hline Bletilla & Bletilla striata & 0 \\
\hline Cinnamomi cortex & Cіпnатотит cassia & 0 \\
\hline Small thistle & Cephalanoplos segetum & 0 \\
\hline Netvein hollyfern & Cyrtomium fortune & 0 \\
\hline Foetid cassia & Cassia obtusifolia & 0 \\
\hline Sneezeweed & Centipede minima & 0 \\
\hline Mandarin peel & Citrus nobilis & 0 \\
\hline Borneol & Dryodalanops aromatic & 0 \\
\hline Chinese dittany & Dictamnus dasycarpus & 0 \\
\hline Ephedra & Ephedra sinica & 0 \\
\hline Epimedium & Epimedium brevicornum & 0 \\
\hline Chinese honeylocust & Gleditsia sinesis & 0 \\
\hline Szechuan & Ligusticum chuanxiong & 0 \\
\hline Chinese motherwort & Leonurus heterophyllus & 0 \\
\hline Lindera & Lindera strychnifolia & 0 \\
\hline Japanese mapoeia & Mahonia japonica & 0 \\
\hline Nutmeg & Myristica frahrans & 0 \\
\hline Notoginseng & Panax notoginseng & 0 \\
\hline Poke & Phytolacca acinosa & 0 \\
\hline Knotweed & Polygoni cuspidate & 0 \\
\hline Chinese senega & Polygala tenuifolia & 0 \\
\hline Chinese foxglove & Rehmannia glutinosa & 0 \\
\hline Radish & Raphanus sativus & 0 \\
\hline Sophora & Sophora flavescens & 0 \\
\hline Tanxiang & Santalum album & 0 \\
\hline Water (control) & & 0 \\
\hline
\end{tabular}

${ }^{y}$ Distance between the bacterial growth and paper disc (clear zone).

${ }^{\mathrm{z}}$ Chinese gallnuts are produced by Rhus chinensis after the stimulation of parasitic aphid Melaphis chinensis. 
that showed a high inhibition, were tested against eight species of phytopathogenic bacteria. Different dilutions of the gallnut aqueous extract and fractions from the silica column chromatography were tested against $A$. citrulli, $R$. solanacearum, $X$. citri pv. citri, and $X$. euvesicatoria (strain XVT-28), which were the most sensitive strains to the gallnut extract. The dry matter of the aqueous extract and the dry matter of the acetone-water extract were made into solutions of $10,5,2.5,1.67,1.25,1,0.67$, and $0.5 \mathrm{mg} / \mathrm{ml}$ and tested for their inhibitory effect on the four test bacteria. To compare the inhibition effect of the gallnut aqueous extract and the compounds that were eluted and purified by column chromatography with that of the commercial products, solutions of each were prepared at concentrations of 5, 2.5, 1.25, 0.625, and $0.3125 \mathrm{mg} / \mathrm{ml}$ in sterile distilled water and were bioassayed.

Minimum inhibitory concentration (MIC) and minimum bactericidal concentration (MBC). To determine the MICs and MBCs of the gallnut aqueous extract and its chemical components, each was incorporated into medium 523 to make concentrations of $4,2,1,0.5$, and $0.25 \mathrm{mg} / \mathrm{ml}$ for the gallnut gallic acid and $0.4,0.2$, $0.1,0.05,0.025$, and $0.0125 \mathrm{mg} / \mathrm{ml}$ for the gallnut aqueous extract and methyl gallate. One loop of a bacterial suspension was streaked on an agar plate that contained different concentrations of a test substance. Three plates were used for each treatment. The bacterial growth was recorded after incubation at $28^{\circ} \mathrm{C}$ for $72 \mathrm{~h}$. The bacteria that were streaked on the plates but did not form colonies after the incubation period were tested for viability by transferring the cells to a fresh plate of medium 523 and incubated at $28^{\circ} \mathrm{C}$ for $72 \mathrm{~h}$. If the bacteria did not grow at this stage, the concentrations of the original plate were recorded as bactericidal. The experiments were repeated twice.

\section{Results}

Effect of the extracts obtained from Chinese medicinal herbs on bacterial growth. Thirty of the 67 aqueous extracts of the Chinese medicinal herbs contained substances that were capable of inhibiting growth of $X$. euvesicatoria (indicated by formation of a clear zone) (Table 2). Among these 30, seven extracts showed strong antibacterial activity and caused inhibition zones of 3.5-6.8

Table 3. Inhibitory effect of the aqueous extracts of gallnut and black myrobalan on the growth of different phytopathogenic bacteria

\begin{tabular}{lcc}
\hline & \multicolumn{2}{c}{ Inhibition zone $(\mathbf{m m})$} \\
\cline { 2 - 3 } Bacteria strain & Gallnut & Black myrobalan \\
\hline Acidovorax citrulli AAC-33 & $11.8 \mathrm{a}^{\mathrm{z}}$ & $5.5 \mathrm{~cd}^{\mathrm{z}}$ \\
Burkholderia cepacia PC & $3.0 \mathrm{~d}$ & $0 \mathrm{e}$ \\
B. gladioli pv. gladioli PK-11 & $2.3 \mathrm{~d}$ & $1.7 \mathrm{~d}$ \\
Pectobacterium carotovorum PCC & $2.8 \mathrm{~d}$ & $0 \mathrm{e}$ \\
P. chrysanthemi PCH & $2.8 \mathrm{~d}$ & $0 \mathrm{e}$ \\
Ralstonia solanacearum EPS-1 & $9.6 \mathrm{~b}$ & $8.8 \mathrm{bc}$ \\
Xanthomonas euvesicatoria XVT-28 & $8.0 \mathrm{c}$ & $8.4 \mathrm{bc}$ \\
X. citri pv. citri XPL-2 & $8.5 \mathrm{bc}$ & $5.6 \mathrm{~cd}$ \\
Water (control) & $0 \mathrm{e}$ & $0 \mathrm{e}$ \\
\hline
\end{tabular}

${ }^{\mathrm{z}}$ Values in each column followed by the same letter are not significantly different $(P=0.05)$ according to Tukey's multiple range test. $\mathrm{mm}, 11$ extracts were moderately inhibitory and caused inhibition zones of 1.7-2.9 mm, and 12 caused inhibition zones of $0.8-1.5$ $\mathrm{mm}$. Gallnut and black myrobalan had the highest antibacterial activities with inhibition zones of 6.8 and $6.6 \mathrm{~mm}$, respectively, and they were selected for further study.

Inhibition effects of the aqueous extracts of gallnut and black myrobalan on plant-pathogenic bacteria. The aqueous extract of gallnut inhibited all eight tested bacteria (Table 3). The most sensitive strain was $A$. citrulli, which had an inhibition zone of $11.8 \mathrm{~mm}$, followed by $R$. solanacearum, $X$. citri pv. citri, and $X$. euvesicatoria, which had inhibition zones between 9.6 and 8.0 $\mathrm{mm}$. The inhibition zones on the four least sensitive species were still between 2.3 and $3.0 \mathrm{~mm}$ (Table 3 ). The aqueous extract of black myrobalan was inhibitory to five of the eight strains, and the resulting inhibition zones ranged from $8.8 \mathrm{~mm}$ on $R$. solanacearum to $1.7 \mathrm{~mm}$ on Burkholderia gladioli pv. gladioli. Burkholderia cepacia, Pectobacterium carotovorum, and P. chrysanthemi were insensitive to the myrobalan extract. These results showed that gallnut had the strongest antibacterial activity. It was, therefore, selected for further tests.

Effect of dilution on the inhibitory effect of gallnut aqueous extract. The growth of all of the tested strains was still inhibited at 800 -fold dilutions of gallnut aqueous extract, but this inhibition was lost when the dilution was 1,600-fold. At the strongest concentration, the inhibition was the highest on $R$. solanacearum, but when the dilutions were in the range of 200- to 400-fold, the inhibitory effect was the same on all of the four tested bacteria (Table 4).

Inhibition effect of the gallnut aqueous extract and acetonewater extract on plant-pathogenic bacteria. The minimum inhibition zone (MIZ) that was produced by the gallnut aqueous extract was at $1 \mathrm{mg} / \mathrm{ml}$ on $A$. citrulli, $R$. solanacearum, and $X$. citri pv. citri, and $0.67 \mathrm{mg} / \mathrm{ml}$ on $X$. euvesicatoria. The MIZ that was produced by the acetone-water extract was at $1 \mathrm{mg} / \mathrm{ml}$ on $X$. citri pv. citri, $1.25 \mathrm{mg} / \mathrm{ml}$ on $R$. solanacearum and $X$. euvesicatoria, and $2.5 \mathrm{mg} / \mathrm{ml}$ on $A$. citrulli (Table 5). These results showed that the antibacterial activity of the aqueous extract was stronger than that of the acetone-water extract, indicating that the two extracts may contain different compositions of the antibacterial compounds.

Compounds isolated from gallnut extract and their antibacterial activity. Freeze-drying the aqueous extract of $4 \mathrm{~kg}$ gallnuts yielded $422 \mathrm{~g}$ of dry matter. Silica column chromatography of the dry matter with a stepwise gradient of $n$-hexane/acetone, acetone/methanol, and 95\% methanol yielded 14 fractions. The fraction that was eluted with 2:3n-hexane:acetone contained a compound with a mobility that was identical to gallic acid on TLC plate $(\mathrm{Rf}=0.7)$. Further purification on a silica gel column $(5 \times 60$ $\mathrm{cm})$ and elution with 3:4:1 $n$-hexane:ethyl acetate:methanol yielded gallic acid $(5 \mathrm{~g})$ as identified by NMR and a literature comparison (21). Another fraction that was eluted with 5:5 acetone:methanol primarily contained a compound with a mobility ( $\mathrm{Rf}$ $=0.86$ ) that was identical to methyl gallate on TLC plate. Its subsequent purification with another silica gel column $(2.5 \times 60 \mathrm{~cm})$ and elution with 1:2 $n$-hexane:acetone yielded methyl gallate (50 $\mathrm{mg}$ ) as identified by NMR and a literature comparison (6). The purity of each compound was confirmed by having only a single

Table 4. Inhibitory effect of the gallnut aqueous extract at different dilutions on four plant-pathogenic bacteria

\begin{tabular}{|c|c|c|c|c|}
\hline \multirow[b]{2}{*}{ Dilution fold } & \multicolumn{4}{|c|}{ Inhibition zone (mm) } \\
\hline & $\begin{array}{c}\text { Acidovorax citrulli } \\
\text { AAC-33 }\end{array}$ & $\begin{array}{c}\text { Ralstonia solanacearum } \\
\text { EPS-1 }\end{array}$ & $\begin{array}{c}\text { Xanthomonas citri pv. citri } \\
\text { XPL-2 }\end{array}$ & $\begin{array}{c}\text { X. euvesicatoria } \\
\text { XVT-28 }\end{array}$ \\
\hline $25 x$ & $5.5 b^{z}$ & $8.0 \mathrm{a}$ & $6.5 \mathrm{ab}$ & $5.8 \mathrm{ab}$ \\
\hline $50 \times$ & $4.5 \mathrm{~b}$ & $7.0 \mathrm{a}$ & $5.2 \mathrm{~b}$ & $5.3 \mathrm{~b}$ \\
\hline $100 \times$ & $4.0 \mathrm{~b}$ & $5.2 \mathrm{a}$ & $4.2 \mathrm{~b}$ & $4.7 \mathrm{ab}$ \\
\hline $200 x$ & $3.2 \mathrm{a}$ & $3.8 \mathrm{a}$ & $3.0 \mathrm{a}$ & $3.7 \mathrm{a}$ \\
\hline $400 \times$ & $2.2 \mathrm{a}$ & $2.2 \mathrm{a}$ & $2.2 \mathrm{ab}$ & $2.5 \mathrm{a}$ \\
\hline $800 \times$ & $1.0 \mathrm{~b}$ & $1.7 \mathrm{ab}$ & $1.7 \mathrm{~b}$ & $1.8 \mathrm{a}$ \\
\hline $1,600 \times$ & 0 & 0 & 0 & 0 \\
\hline Water (control) & 0 & 0 & 0 & 0 \\
\hline
\end{tabular}

${ }^{z}$ Values in each row followed by the same letter are not significantly different $(P=0.05)$ according to Tukey's multiple range test. 
Table 5. Inhibitory effect of water and water-acetone extracts of gallnut on four plant pathogenic bacteria

\begin{tabular}{|c|c|c|c|c|}
\hline \multirow[b]{2}{*}{ Concentration (mg/ml) } & \multicolumn{4}{|c|}{ Inhibition zone (mm) } \\
\hline & $\begin{array}{c}\text { Acidovorax citrulli } \\
\text { AAC-33 }\end{array}$ & $\begin{array}{c}\text { Ralstonia solanacearum } \\
\text { EPS-1 }\end{array}$ & $\begin{array}{c}\text { Xanthomonas citri pv. citri } \\
\text { XPL-2 }\end{array}$ & $\begin{array}{c}\text { X. euvesicatoria } \\
\text { XVT-28 }\end{array}$ \\
\hline \multicolumn{5}{|l|}{ Water extract } \\
\hline 10.00 & $3.3 \mathrm{a}^{\mathrm{y}}$ & $3.8 \mathrm{a}$ & $3.2 \mathrm{a}$ & $3.7 \mathrm{a}$ \\
\hline 5.00 & $2.2 \mathrm{~b}$ & $2.5 \mathrm{~b}$ & $2.5 \mathrm{~b}$ & $2.3 \mathrm{~b}$ \\
\hline 2.50 & $1.5 \mathrm{c}$ & $1.8 \mathrm{c}$ & $1.8 \mathrm{c}$ & $1.8 \mathrm{c}$ \\
\hline 1.67 & $1.2 \mathrm{~cd}$ & $1.5 \mathrm{c}$ & $1.5 \mathrm{c}$ & $1.0 \mathrm{~cd}$ \\
\hline 1.25 & $0.8 \mathrm{~d}$ & $1.2 \mathrm{c}$ & $1.2 \mathrm{c}$ & $0.7 \mathrm{~d}$ \\
\hline 1.00 & $0.6 \mathrm{~d}$ & $0.8 \mathrm{~d}$ & $0.5 \mathrm{~d}$ & $0.5 \mathrm{~d}$ \\
\hline 0.67 & $0 \mathrm{e}$ & $0 \mathrm{e}$ & $0 \mathrm{e}$ & $0.3 \mathrm{de}$ \\
\hline 0.50 & $-{ }^{\mathrm{z}}$ & - & - & $0 \mathrm{e}$ \\
\hline \multicolumn{5}{|l|}{ Acetone-water extract } \\
\hline 10.00 & $1.7 \mathrm{c}$ & $3.0 \mathrm{ab}$ & $2.5 \mathrm{~b}$ & $2.8 \mathrm{ab}$ \\
\hline 5.00 & $1.0 \mathrm{~cd}$ & $1.8 \mathrm{c}$ & $1.7 \mathrm{c}$ & $2.2 \mathrm{~b}$ \\
\hline 2.50 & $0.7 \mathrm{~d}$ & $1.1 \mathrm{~cd}$ & $1.2 \mathrm{c}$ & $0.8 \mathrm{~d}$ \\
\hline 1.67 & $0 \mathrm{e}$ & $0.7 \mathrm{~d}$ & $1.0 \mathrm{c}$ & $0.5 \mathrm{~d}$ \\
\hline 1.25 & - & $0.5 \mathrm{~d}$ & $0.8 \mathrm{~cd}$ & $0.2 \mathrm{de}$ \\
\hline 1.00 & - & $0 \mathrm{e}$ & $0.3 \mathrm{de}$ & $0 \mathrm{e}$ \\
\hline 0.67 & - & - & $0 \mathrm{e}$ & - \\
\hline Water (control) & $0 \mathrm{e}$ & $0 \mathrm{e}$ & $0 \mathrm{e}$ & $0 \mathrm{e}$ \\
\hline
\end{tabular}

y Values in each column followed by the same letter are not significantly different $(P=0.05)$ according to Tukey's multiple range test.

${ }^{\mathrm{z}}$ Not tested.

Table 6. Inhibitory effect of various concentrations of gallic acid and methyl gallate that were isolated from gallnut extract or purchased from chemical companies on four plant pathogenic bacteria

\begin{tabular}{|c|c|c|c|c|c|c|c|c|}
\hline \multirow{3}{*}{$\begin{array}{l}\text { Concentrations } \\
(\mathrm{mg} / \mathrm{ml})\end{array}$} & \multicolumn{8}{|c|}{ Inhibition zone (mm) } \\
\hline & \multicolumn{2}{|c|}{$\begin{array}{c}\text { Acidovorax citrulli } \\
\text { AAC-33 }\end{array}$} & \multicolumn{2}{|c|}{$\begin{array}{c}\text { Ralstonia solanacearum } \\
\text { EPS-1 }\end{array}$} & \multicolumn{2}{|c|}{$\begin{array}{c}\text { Xanthomonas citri pv. citri } \\
\text { XPL-2 }\end{array}$} & \multicolumn{2}{|c|}{$\begin{array}{l}\text { X. euvesicatoria } \\
\text { XVT-28 }\end{array}$} \\
\hline & Gallnut & Commercial & Gallnut & Commercial & Gallnut & Commercial & Gallnut & Commercial \\
\hline \multicolumn{9}{|l|}{ Gallic acid } \\
\hline 100 & $5.7 \mathrm{fg}^{\mathrm{y}}$ & $4.9 \mathrm{gh}$ & $3.7 \mathrm{fg}$ & $3.5 \mathrm{fg}$ & 3.7 efg & $3.0 \mathrm{gh}$ & $2.0 \mathrm{hi}$ & $1.5 \mathrm{ij}$ \\
\hline 50 & $1.4 \mathrm{ijk}$ & $1.2 \mathrm{jk}$ & 1.9 ghij & $3.2 \mathrm{fgh}$ & $0.9 \mathrm{ij}$ & $1.0 \mathrm{hij}$ & $0.7 \mathrm{ij}$ & $0.9 \mathrm{ij}$ \\
\hline 20 & $0 \mathrm{k}$ & $0 \mathrm{k}$ & $0 \mathrm{j}$ & $1.2 \mathrm{hij}$ & $0 \mathrm{j}$ & $0 \mathrm{j}$ & $0 \mathrm{j}$ & $0 \mathrm{j}$ \\
\hline 10 & $-{ }^{\mathrm{z}}$ & - & - & $0 \mathrm{j}$ & - & - & - & - \\
\hline \multicolumn{9}{|l|}{ Methyl gallate } \\
\hline 100 & $17.7 \mathrm{ab}$ & $20.0 \mathrm{a}$ & $13.4 \mathrm{~b}$ & $16.0 \mathrm{a}$ & $11.2 \mathrm{ab}$ & $12.4 \mathrm{a}$ & $12.7 \mathrm{~b}$ & $14.7 \mathrm{a}$ \\
\hline 50 & $13.7 \mathrm{~d}$ & $16.4 \mathrm{bc}$ & $8.7 \mathrm{de}$ & $13.7 \mathrm{~b}$ & $8.0 \mathrm{c}$ & $10.0 \mathrm{~b}$ & $10.7 \mathrm{~cd}$ & $11.0 \mathrm{bc}$ \\
\hline 20 & $9.0 \mathrm{e}$ & $14.7 \mathrm{~cd}$ & $5.4 \mathrm{f}$ & $12.4 \mathrm{bc}$ & $5.4 \mathrm{def}$ & $7.0 \mathrm{~cd}$ & $6.0 \mathrm{e}$ & $7.5 \mathrm{de}$ \\
\hline 10 & $7.5 \mathrm{ef}$ & $12.7 \mathrm{~d}$ & $4.0 \mathrm{fg}$ & $10.4 \mathrm{~cd}$ & $3.5 \mathrm{fgh}$ & $5.5 \mathrm{de}$ & $5.4 \mathrm{f}$ & $6.2 \mathrm{e}$ \\
\hline 5 & $3.7 \mathrm{ghi}$ & $8.5 \mathrm{e}$ & $3.4 \mathrm{fgh}$ & $7.9 \mathrm{e}$ & 1.7 ghi & 3.7 efg & $4.7 \mathrm{fg}$ & $4.5 \mathrm{fg}$ \\
\hline 2.5 & 3.4 ghij & $5.4 \mathrm{fg}$ & $2.4 \mathrm{ghi}$ & $5.4 \mathrm{f}$ & $0 \mathrm{j}$ & $1.2 \mathrm{hij}$ & $3.2 \mathrm{gh}$ & $3.4 \mathrm{gh}$ \\
\hline 1.25 & $2.7 \mathrm{hij}$ & $4.5 \mathrm{gh}$ & 1.9 ghij & $3.7 \mathrm{fg}$ & - & $0 \mathrm{j}$ & $2.2 \mathrm{hi}$ & $1.2 \mathrm{ij}$ \\
\hline 0.625 & $1.2 \mathrm{jk}$ & $1.5 \mathrm{ijk}$ & $0.5 \mathrm{ij}$ & 1.9 ghij & - & - & $0 \mathrm{j}$ & $0 \mathrm{j}$ \\
\hline 0.3125 & $0 \mathrm{k}$ & $0 \mathrm{k}$ & $0 \mathrm{j}$ & $0 \mathrm{j}$ & - & - & - & - \\
\hline
\end{tabular}

y Values in columns under a bacterial strain followed by the same letter are not significantly different $(P=0.05)$ according to Tukey's multiple range test.

${ }^{\mathrm{z}}$ Not tested.

spot on the TLC plate. The inhibitory effects on bacterial growth that were caused by these fractions and their corresponding commercial chemicals are shown in Table 6. The gallic acids had weak antibacterial activity. The MIZ of commercial gallic acid was produced at $20 \mathrm{mg} / \mathrm{ml}$ on $R$. solanacearum, and the MIZs for the commercial and gallnut gallic acids were produced at $50 \mathrm{mg} / \mathrm{ml}$ on the other three bacteria (Table 6). The commercial methyl gallate showed the same or a better inhibitory effect on all of the tested bacterial strains as compared to gallnut methyl gallate (Table 6). The MIZ of gallnut methyl gallate was produced at $5 \mathrm{mg} / \mathrm{ml}$ on $X$. citri pv. citri and $0.625 \mathrm{mg} / \mathrm{ml}$ on $A$. citrulli and $R$. solanacearum; the MIZ of commercial and gallnut methyl gallate was produced at $1.25 \mathrm{mg} / \mathrm{ml}$ on $X$. euvesicatoria (Table 6). Streptomycin, which was the positive control, showed a stable inhibitory effect on the four tested bacteria. The inhibition zones were 5 to $10 \mathrm{~mm}$ at concentrations ranging from 0.3 to $2 \mathrm{mg} / \mathrm{ml}$.

MIC and MBC of gallnut aqueous extract and its chemical components. Gallic acid that was purified from the gallnut extract was the weakest inhibitor of the growth of the tested bacteria. Its MICs on A. citrulli, $R$. solanacearum, $X$. citri pv. citri, and $X$. euvesicatoria were 4, 1, 4, and $2 \mathrm{mg} / \mathrm{ml}$, and the MBCs were 4, 2,
4 , and $4 \mathrm{mg} / \mathrm{ml}$, respectively (Table 7). The methyl gallate that was purified from the gallnut extract demonstrated very strong antibacterial activities. The best effect was on A. citrulli with an MIC and $\mathrm{MBC}$ of $0.05 \mathrm{mg} / \mathrm{ml}$. Gallnut MIC on $R$. solanacearum, $X$. citri pv. citri, and $X$. euvesicatoria was $0.1 \mathrm{mg} / \mathrm{ml}$, and the MBCs were $0.1,0.1$, and $0.2 \mathrm{mg} / \mathrm{ml}$, respectively. The dry matter of the gallnut aqueous extract also demonstrated strong antibacterial activity; the maximum inhibition was on A. citrulli, and the MIC was $0.025 \mathrm{mg} / \mathrm{ml}$. The MIC on the three other bacterial species was $0.05 \mathrm{mg} / \mathrm{ml}$. The MBCs on A. citrulli, $R$. solanacearum, X. citri pv. citri, and $X$. euvesicatoria were $0.25,0.1,0.05$, and $0.05 \mathrm{mg} / \mathrm{ml}$, respectively (Table 7). These results showed that the inhibitory trends of methyl gallate toward the tested bacteria were similar to those of the gallnut aqueous extract; the latter was 1 to 4 times more inhibitory at the tested concentrations. The mixtures of gallic acid and methyl gallate did not increase the antibacterial effect (data not shown).

\section{Discussion}

More than $44 \%$ of the extracts of the 67 Chinese herbal medicines tested in this study contained substances inhibitory to the 
Table 7. Minimum inhibitory concentration (MIC) and minimum bactericidal concentration (MBC) of gallic acid, methyl gallate, and the aqueous extract of gallnut on plant pathogenic bacteria

\begin{tabular}{|c|c|c|c|c|c|c|}
\hline \multirow[b]{2}{*}{ Tested bacteria } & \multicolumn{2}{|c|}{ Gallic acid (mg/ml) } & \multicolumn{2}{|c|}{ Methyl gallate (mg/ml) } & \multicolumn{2}{|c|}{ Aqueous extract $(\mathrm{mg} / \mathrm{ml})$} \\
\hline & MIC & MBC & MIC & MBC & MIC & MBC \\
\hline Acidovorax citrulli AAC-33 & 4.0 & 4.0 & 0.05 & 0.05 & 0.025 & 0.025 \\
\hline Ralstonia solanacearum EPS-1 & 1.0 & 2.0 & 0.10 & 0.10 & 0.050 & 0.100 \\
\hline Xanthomonas citri pv. citri XPL-2 & 4.0 & 4.0 & 0.10 & 0.10 & 0.050 & 0.050 \\
\hline X. euvesicatoria XVT-28 & 2.0 & 4.0 & 0.10 & 0.20 & 0.050 & 0.050 \\
\hline
\end{tabular}

growth of $X$. euvesicatoria. Among the tested plant materials, gallnut and black myrobalan showed the strongest antibacterial activity. Our previous research showed that the aqueous extract of gallnut inhibited the conidial germination of many phytopathogenic fungi (8). In the current study, the aqueous extract of gallnut inhibited eight plant-pathogenic bacterial species including A. citrulli, $R$. solanacearum, $X$. euvesicatoria, and $X$. citri pv. citri, while the aqueous extract of black myrobalan inhibited five of the eight species in the same test. The gallnut aqueous extract retained its activity against four plant bacterial pathogens at dilutions of up to 800fold. These results demonstrate that aqueous extract of gallnut has a strong potential for use in the control of plant bacterial diseases. The inhibitory effect of the gallnut aqueous extract was stronger than that of the acetone-water extract, suggesting that more of the inhibitory compounds were extracted by the heat extraction (autoclave). Freeze-drying the aqueous extract of $4 \mathrm{~kg}$ of gallnuts yielded $422 \mathrm{~g}$ of dry matter. The MIZ of the aqueous extract was produced at dilutions between 800- and 1,600-fold, and that of the dry matter from the aqueous extract was between $1,000-(1 \mathrm{mg} / \mathrm{ml})$ and 1,500-fold dilution. The inhibitory effect of the dry matter was about one-tenth of its original aqueous extract. Further study is required to optimize the preparation of the dry matter from the aqueous extract in order to lower the cost and to better preserve the inhibitory effects.

Gallic acid and methyl gallate were two of the chemical components in the gallnut. These have previously been shown to inhibit the growth of microorganisms that are found in oral cavities and the intestinal tract, and of foodborne infection bacteria $(1,6,7,13)$. These chemicals may also control the growth of fungal pathogens on crops (2). Gallic acid lost its inhibitory effect on tested intestinal bacteria at $1 \mathrm{mg} / \mathrm{disc}$ (1) and had MIC $\geqq 1 \mathrm{mg} / \mathrm{ml}$ on oral bacteria (13). In this study, gallic acid slightly inhibited the growth of four plant pathogenic bacteria. The MIC was 1 to $4 \mathrm{mg} / \mathrm{ml}$, and the MIZs were produced at concentrations ranging from 20 to 50 $\mathrm{mg} / \mathrm{ml}$. The paper discs that were used in this study could absorb about $10 \mu \mathrm{l}$ of solution. This indicates that the plant-pathogenic bacteria that were tested are as sensitive or more sensitive to gallic acid than those that were tested in previous reports. Our results also indicate that gallic acid is not the major antibacterial compound in gallnut extract. Methyl gallate has also been found to require 5 to $10 \mathrm{mg} /$ disc to produce its MIZ (1). In this study, methyl gallate that was isolated from gallnut could produce a MIZ from 0.625 to $5 \mathrm{mg} / \mathrm{ml}$ (approximately 6.26 to $50 \mu \mathrm{g} / \mathrm{disc}$ ) on the four tested bacteria; this demonstrates the high sensitivity of the plant-pathogenic bacteria. Methyl gallate was reported to have MICs on eight intestinal bacteria from 0.25 to $1 \mathrm{mg} / \mathrm{ml}$ (7) and on seven foodborne infectious bacteria from 0.03 to $0.125 \mathrm{mg} / \mathrm{ml}(6)$. In the current study, the MICs were from 0.05 to $0.1 \mathrm{mg} / \mathrm{ml}$ on plant-pathogenic bacteria. Comparative tests between the MIC and $\mathrm{MBC}$ of gallnut aqueous extract and methyl gallate showed that the original extract had twice the inhibitory effect in MIC and 1 to 4 times the effect in MBC; however, the inhibitory spectrum and the trends toward the tested bacteria were similar for both. Our results indicate that methyl gallate that is isolated from the Chinese sumac gallnut could be an important inhibitory compound toward plantpathogenic bacteria, and there are other unidentified compounds that are also responsible for the antibacterial effects. This is the first report regarding the strong antibacterial effects of gallnut extracts and their chemical components on plant-pathogenic bacteria.

\section{Literature Cited}

1. Ahn, Y., Lee, C., Kweon, J., Ahn, J., and Park, J. 1998. Growth-inhibitory effects of Galla Rhois-derived tannins on intestinal bacteria. J. Appl. Microbiol. 84:439-443.

2. Ahn, Y., Lee, H., Oh, H., Kim, H., and Lee, Y. 2005. Antifungal activity and mode of action of Galla rhois-derived phenolics against phytopathogenic fungi. Pestic. Biochem. Physiol. 81:105-112.

3. Balestra, G. M., Heydari, A., Ceccarelli, D., Ovidi, E., and Quattrucci, A. 2009. Antibacterial effect of Allium sativum and Ficus carica extracts on tomato bacterial pathogens. Crop Prot. 28:807-811.

4. Chen, K. C. 2004. Study on the chemical constituents and bioactivities of gall of Rhus semialata. M.S. thesis. Institute of Life Science, National Tsing Hua University. Taiwan. (in Chinese)

5. Cheng, A. H., Hsu, Y. L., Huang, T. C., and Wang, H. L. 2000. Susceptibility of cucurbits to Acidovorax avenae subsp. citrulli and control of fruit blotch on melon. Plant Pathol. Bull. 9:151-156. (in Chinese)

6. Choi, J., Kang, O., Lee, Y., Oh, Y., Chae, H., Jang, H., Kim, J., Sohn, D., Shin, D., Park, H., and Kwon, D. 2008. In vitro activity of methyl gallate from Galla Rhois alone and in combination with ciprofloxacin against clinical isolates of Sammonella. J. Microbiol. Biotechnol. 18:1848-1852.

7. Choi, J., Kang, O., Lee, Y., Oh, Y., Chae, H., Jang, H., Shin, D., and Kwon, D. 2009. Antibacterial activity of methyl gallate isolated from Galla rhois or carvacrol combined with nalidixic acid against nalidixic acid resistant bacteria. Molecules 14:1773-1780.

8. Ho, W. C., Su, H. J., Li, J. W., and Ko, W. H. 2006. Effect of extracts of Chinese medicinal herbs on spore germination of Alternaria brassicicola, and nature of an inhibitory substance from gallnuts of Chinese sumac (Rhus chinensis). Can. J. Plant Pathol. 28:519-525.

9. Hopkins, D. L., Thompson, C. M., Hilgren, J., and Lovic, B. 2003. Wet seeds treatment with peroxyacetic acid for control of bacterial fruit blotch and other seed-borne diseases of watermelon. Plant Dis. 87:1495-1499.

10. Iacobellis, N. S., Cantore, P. L., Capasso, F., and Senatore, F. 2005. Antibacterial activity of Cuminum cyminum L. and Carum carvi L. essential oils. J. Agric. Food Chem. 53:57-61.

11. Ji, P., Momol, M. T., Olson, S. M., Pradhanang, P. M., and Jones, J. B. 2005. Evaluation of thymol as biofumigant for control of bacterial wilt of tomato under field conditions. Plant Dis. 89:497-500.

12. Kado, C. I., and Heskett, M. G. 1970. Selective media for isolation of Agrobacterium, Corynebacterium, Erwinia, Pseudomonas, and Xanthomonas. Phytopathology 60:969-976.

13. Kang, M., Oh, J., Kang, I., Hong, S., and Choi, C. 2008. Inhibitory effect of methyl gallate and gallic acid on oral bacteria. J. Microbiol. 46:744-750.

14. Lin, C. H., Hsu, S. T., Tzeng, K. C., and Wang, J. F. 2008. Application of a preliminary screen to select locally adapted resistant rootstock and soil amendment for integrated management of tomato bacterial wilt in Taiwan. Plant Dis. 92:909-916.

15. Mahlo, S. M., McGaw, L. J., and Eloff, J. N. 2010. Antifungal activity of leaf extracts from Sourth African trees against plant pathogens. Crop Prot. 29:1529-1533.

16. Marco, G. M., and Stall, R. E. 1983. Control of bacterial spot of pepper in sensitivity to copper. Plant Dis. 67:779-781.

17. Obradovic, A., Jones, J. B., Momol, M. T., Olson, S. M., Jackson, L. E., Balogh, B., Guven, K., and Iriarte, F. B. 2005. Integration of biological control agents and systemic acquired resistance inducers against bacterial spot on tomato. Plant Dis. 89:712-716.

18. Parker, P. E., Bock, C. H., and Gottwald, T. R. 2005. Comparison of techniques to sample Xanthomonas citri pv. citri in windblown spray. Plant Dis. 89:1324-1330.

19. Pradhanang, P. M., Momol, M. T., Olson, S. M., and Jones, J. B. 2003. Effects of plant essential oils on Ralstonia solanacearum population density and bacterial wilt incidence in tomato. Plant Dis. 87:423-427.

20. Sucharitha, A., and Uma Maheswari Devi, P. 2010. Antimicrobial properties of chilli lipoxygenase products. Afr. J. Microbiol. Res. 4:748-752

21. Tian, G., Zhang, T., Yang. F., and Ito, Y. 2000. Separation of gallic acid from Cornus officinalis Sieb. et Zucc by high-speed counter-current chromatography. J. Chromatogr. A. 886:309-312.

22. Wilson, C. L., Solar, J. M., El Ghaouth, A., and Wisniewski, M. E. 1997. Rapid evaluation of plant extracts and essential oils for antifungal activity against Botrytis cinerea. Plant Dis. 81:204-210. 